\title{
Pembelajaran Mitigasi Bencana di Sekolah Dasar dengan Metode Demonstrasi
}

\author{
Disaster Mitigation Learning in Elementary School using Demonstration Method \\ Wita Salwa Salsabila ${ }^{1}$, Rachmah Rafa Dinda ${ }^{2}$ \\ ${ }^{1,2}$ Program Studi Pendidikan Guru Sekolah Dasar Universitas Muhammadiyah Purwokerto
}

\section{ARTICLE INFO}

Article history:

DOI:

10.30595/pssh.v1i.83

Submitted:

April 12, 2021

Accepted:

June 10, 2021

Published:

June 14, 2021

\section{Keywords:}

ABSTRACT

Geographically Indonesia is an island nation and has a greater sea area than land and is at the confluence of three plates namely, the Pacific plate, indoaustralis and also Eurasia. This makes indonesia as one of the countries that are often hit by disasters. Disaster mitigation education based on local wisdom is conducted in the 2013 curriculum by (1) identifying local wisdom in disaster mitigation, (2) integrating in learning. With the understanding of disaster mitigation is expected to be the basis for learners to be able to take action to reduce the influence of a hazard before the danger occurs. And it can also be one of the solutions that can be done in Indonesia to reduce the impact of disasters that can result in accidents and even deaths. This research aims to develop disaster mitigation models in elementary schools. The results of disaster education research is one of the solutions in schools to reduce the impact of disasters, as well as familiarize students to be responsive and ready for disasters. Therefore, disaster learning model needs to be developed assuming that the focus of mitigation now is not about disaster management, but refers to the understanding of responsiveness. Disaster learning should be provided through a demonstration model that can involve cognitive, affective, and psychomotor spheres in the framework of disaster mitigation.
\end{abstract}

Mitigation Disaster, Demonstration Model
This work is licensed under a Creative Commons Attribution 4.0 International License.

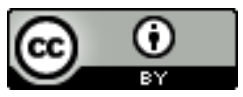

\author{
Corresponding Author: \\ Rahajeng Win Martani \\ Department of Nursing, \\ Health Science Faculty, Universitas Pekalongan \\ Jalan Sriwijaya No.3 Pekalongan, Jawa Tengah, Indonesia. \\ Email: ajeng.winmarta@gmail.com
}

\section{PENDAHULUAN}

Bencana alam merupakan salah satu peristiwa yang dapat mengancam manusia setiap saat dan menimbulkan kerusakan terhadap lingkungan. Bencana dapat terjadi diseluruh belahan dunia diantaranya gempa bumi dan tsunami. Ada bencana yang dapat di upayakan untuk tidak terjadi, tetapi ada bencana yang tidak dapat dihindari. (Undang-Undang Nomor 24 Tahun 2007 tentang Penanggulangan Bencana). Sehingga mengakibatkan timbulnyaa korban jiwa, kerusakan lingkungan, kerugian harta benda, dan dampak psikologis.

Secara geologis, Indonesia menjadi pertemuan antara tiga lempeng tektonik aktif yaitu lempeng Indo-australia lempeng Eurasia dan lempeng pasifik. Oleh karena itu, berbagai fenomena seperti gempa bumi dan erupsi gunung api sering terjadi diIndonesia (Setiawan (2014) dalam Hermon 2015:2) . Dengan demikian Indonesia memiliki berbagai bahaya bencana yang dapat terjadi kapanpun. Disamping itu masyarakat perlu kesiapan menghadapi bencana melalui Pendidikan bencana.

Pendidikan bencana berupaya untuk memperkuat langkah perlindungan dan memberikan suatu pembelajaran tentang bahaya atau risiko yang ditimbulkan. Jika dibuat secara terstuktur kemudian dilaksanakan secara benar, masyarakat bisa dengan mudah memperagakan segala bentuk praktek keselamatan yang berkaitan dengan 
bencana. Pengurangan risiko bencana dan pendidikan pencegahan dirancang guna membangun keselamatan masyarakat. Pendidikan kebencanaan adalah salah satu solusi internal di masyarakat untuk mengurangi dampak bencana, serta membiasakan masyarakat untuk tanggap dan sigap terhadap bencana yang terjadi. Pendidikan kebencanaan memiliki berbagai bentuk dimulai dari penangulangan bencana di masyarakat, pendidikan kebencanaan menuju masyarakat sadar bencana, dan kearifan local masyarakat menangani bencana (Preston (2012) dalam Setyowati 2007). Pendidikan kebencanaan bagi masyarakat sadar bencana merupakan metode atau metode untuk memahami konsep kebencanaan yang bertujuan untuk mengembangkan pemahaman dan pengetahuan yang dibutuhkan untuk beradaptasi dengan lingkungan yang berada di daerah yang sering terjadi bencana. Pengertian model kebencanaan adalah upaya untuk mewujudkan masyarakat peduli, memiliki pengetahuan serta keterampilan untuk mencegah masalah bencana dan menghindari kemungkinan masalah bencana di kemudian hari.

Pembelajaran kebencanaan hendaknya diberikan melalui model demonstrasi yang melibatkan tiga ranah aspek penilaian mitigasi bencana (Rusilowati, 2009). Dengan menggunakan model pembelajaran kebencanaan nantinya peserta didik dapat melibatkan ranah kognitif, afektif dan psikomotorik sebagaimana pembelajaran kebencanaan lebih menekankan kepada cara mencegah masalah bencana. Untuk perlu dikembangkan model pembelajaran kebencanaan dengan asumsi bahwa focus mitigasi sekarang bukan hanya menyangkut penanganan bencana, namun lebih merujuk kepada pengertian kesiapan didalam peserta didik menanggulanggi permasalahan bencana alam. Tujuan pembelajaran mitigasi bencana kepada masyarakat adalah meningkatkan warga dengan kapasitas untuk mengatasi bencana tidak hanya selama dan setelah bencana tetapi juga sebelum bencana (Maryani, 2010).

Model pembelajaran mitigasi bencana adalah pembelajaran yang operasionalnya menggunakan alur: (1) persiapan sebelum bencana itu berlangsung, (2) menilai bahaya bencana, (3) penanggulangan bencana, berupa penyelamatan, rehabilitasi dan relokasi, (4) pemberian pengeta-huan, pemahaman dan keterampilan berprilaku dalam mencegah, (5) pendeteksian dan antipasti bencana secara efektif dapat ditransformasikan, dan (6) pensosialisasian (Maryani, 2010). Suatu proses pembelajaran notaben melibatkan beberapa perangkat, baik fisik maupun non fisik Nampak dalam proses pembelajaran. Hal-hal seperti guru, siswa sarana ruang kelas, media dan alat peraga pembelajaran secara fisik hadir dalam proses pembelajaran diantaranya kurikulum, strategi dan metode pembelajaran yang digunakan.

Penguasan kemampuan mitigasi bencana bagi siswa sekolah dasar begitu penting karena bermanfaat hingga dewasa. Metode demonstrasi dapat memberikan ilustrasi dan menjelaskan informasi pada anak, dan dapat meningkatkan daya pikir anak dalam kemampuan mengenal, mengingat, berpikir konvergen dan evaluatif (Cahyani, Jampel, \& Ujianti, 2015). Pengertian metode demonstrasi menurut Syah (2000: 208) adalah metode mengajar dengan cara memperagakan barang, kejadian, aturan dan urutan melakukan kegiatan, baik secara langsung maupun melalui penggunaan media pengajaran yang relevan dengan pokok bahasan atau materi yang sedang disajikan. Menurut Rusminiati (2007:2) metode demonstrasi merupakan peragaan pada suatu peristiwa, maupun tingkah laku yang dicontohkan supaya peserta didik atau siswa dalam suatu kelas dapat memahami dengan mudah. Metode demonstrasi menurut Bahri \& Zain (2006:91) suatu proses yang dapat membuat cara mengajar menjadi lebih bermakna yang nantinya siswa lebih dapat memahami apa yang dipelajari, cara mengajar lebih kreatif yang membuat peserta didik dapat menyesuaikan antara materi dengan keadaan saat ini.

Dari beberapa pendapat para ahli maka Pengunaan metode demonstrasi dalam pembelajaran mitigasi bencana yaitu karena metode demonstrasi adalah cara penyajian pembelajaran dengan memperagakan dan mempertunjukkan suatu proses, situasi atau benda tertentu yang sedang dipelajari baik dalam bentuk sebenarnya maupun dalam bentuk tiruan yang dipertunjukkan oleh guru atau sumber belajar lain di depan seluruh siswa. Dengan menggunakan metode demonstrasi diharapkan siswa dapat memperjelas pengertian konsep dan memperlihatkan cara melakukan sesuatu atau proses terjadinya sesuatu selain itu juga proses penerimaan siswa terhadap pelajaran akan lebih berkesan secara mendalam, sehingga membentuk pengertian dengan baik dan sempurna. Pendidikan menjadi salah satu sarana yang efektif untuk mengurangi risiko bencana dengan memasukkan materi pelajaran tentang bencana alam sebagai pelajaran wajib bagi setiap siswa di semua tingkatan, terutama di sekolah-sekolah yang berada di wilayah risiko bencana.

Berdasarkan identifikasi masalah diatas, rumusan masalah pada penelitian ini adalah bagaimana Pembelajaran mitigasi bencana di sekolah dasar masih belum banyak diberikan guru terutama didaerah rawan bencana dan bagaimana guru belum menerapkan metode demonstrasi dalam pembelajaran mitigasi bencana disekolah dasar.

Tujuan dari penelitian ini adalah untuk mengetahui model pembelajaran demonstrasi dalam pembelajaran mitigasi bencana. Penelitian ini merangkum beberapa informasi mengenai pembelajaran mitigasi bencana tersebut. Untuk dapat memberikan pembelajaran mitigasi bencana kepada peserta didik yang nantinya mampu mengajarkan pembelajaran tersebut pada keluarga sehingga dapat siap dengan adanya bencana. 


\section{METODE PENELITIAN}

Penelitian ini bertujuan untuk mengajarkan metode pembelajaran demonstrasi pada pembelajaran mitigasi bencana di Sekolah Dasar. Menurut Hasibuan, Zainal A. (2007), tinjauan pustaka memuat gambaran tentang teori, hasil dan bahan penelitian lainny dari bahan referensi yang digunakan sebagai dasar kegiatan penelitian. Menurut Yudi Agusta, PhD (2007) mengenai Metode Penelitian : "kajian pustaka adalahh analisis kritis penelitian terhadap topik atau subjek tertentu dalam bidang ilmiah", yang berarti kajian pustaka mmerupakananalisis kritis penelitian terhadap suatu subjek atau bentuk tertentu. Menjawab pertanyaan dibagian sains. Tinjauan pustaka dapat diartikan sebagai deskripsi teori. Hasil yang diperoleh dari bahan referensi dan bahan penelitian lainnya dapat dijadikan dasar kegiatan penelitian, sehingga memberikan kerangka psikologis yang jelas bagi rumusan pertayaan penelitian. Adapun langkah-langkah yang dilakukan dalam kajian literatur ini diantaranya mendefinisikan ruang lingkup topik yang akan direview, mengidentifikasikan sumber-sumber yang relevan, mereview literatur, menulis literatur dan mengaplikasikan literatur pada kajian yang akan dilakukan.

\section{HASIL DAN PEMBAHASAN}

Bencana adalah peristiwa atau rangkaian peristiwa yang mengancam dan mengganggu kehidupan masyarakat yang disebabkan, baik oleh faktor alam atau faktor nonalam atau faktor manusia sehingga mmenimbulkan korban jiwa, kerusakan lingkungan, kerugian harta benda, dan psikologis. Oleh karena itu, Undang-Undang Nomor 24 Tahun 2007 tersebut juga mendefinisikan tentang bencana alam, bencana nonalam, dan bencana sosial. Sedangkan definisi bencana (disaster) menurut WHO (2002) adalah setiap kejadian yang menyebabkan kerusakan, gangguan ekologis, hilangnya nyawa Manusia, atau memburuknya derajat kesehatan atau pelayanan kesehatan pada skala tertentu yang memerlukan respon dari luar masyarakat atau wilayah yang terkena.

Wijayanto (2012), Bencana adalah suatu gangguan serius terhadap masyarakat yang menimbulkan kerugian secara meluas dan dirasakan baik oleh masyarakat, berbagai material dan lingkungan (alam) dimana dampak yang ditimbulkan melebihi kemampuan manusia guna mengatasinya dengan sumber daya yang ada. Lebih lanjut, Parker (1992) dalam dikutip Wijayanto (2012), bencana adalah sebuah kejadian yang tidak biasa terjadi disebabkan oleh alam maupun ulah manusia, termasuk pula di dalamnya merupakan imbas dari kesalahan teknologi yang memicu respon dari masyarakat, komunitas, individu maupun lingkungan untuk memberikan antusiasme yang bersifat luas

Bencana alam dapat diartikan suatu bencana diakibatkan oleh gejala alam. Gejala alam merupakan gejala yang alamiah dan bisa terjadi dibumi. Namun, hanya ketika gejala alam tersebut melanda manusia dan segala produk kepemilikan, harta dan benda, dapat menyebutnya sebagai bencana. Kerugian yang ditimbulkan bergantung kemampuannya untuk menghindari bencana dan ketahanannya. Oleh karena itu, kegiatan alam yang berbahaya tidak akan menjadi bencana alam di wilayah tanpa bantuan manusia, seperti gempa bumi di wilayah yang tidak berpenghuni. Oleh karena itu penggunaan istilah "alam" juga ditentang, karena tanpa partisipasi manusia, peristiwa tersebut tidak hanya sekedar bahaya atau bencana. Tingkat keparahan potensi kerusakan juga bergantung pada bentuk bahayanya itu sendiri, mulai dari kebakaran yang mengancam satu bangunan hingga dampak bencana yang sangat besat juga dapat membahayakan manusia

Mitigasi bencana adalah serangkaian upaya untuk mengurangi risiko bencana, baik melalui pembangunan fisik maupun penyadaran dan peningkatan kemampuan menghadapi ancaman bencana (Pasal 1 ayat 6 PP No 21 Tahun 2008 tentang Penyelenggaraan Penanggulangan Bencana). Mitigasi didefinisikan sebagai upaya yang ditujukan untuk mengurangi dampak dari bencana, Mitigasi adalah serangkaian upaya untuk mengurangi risiko bencana, baik melalui pembangunan fisik maupun penyadaran dan peningkatan kemampuan menghadapi ancaman bencana. (UU No 24 Tahun 2007, Bab I Ketentuan Umum, Pasal 1 angka 9) (PP No 21 Tahun 2008, Bab I Ketentuan Umum, Pasal 1 angka 6).

Menurut Astuti dan Sudaryono (2010) sebagai negara yang sangat rawan bencana alam, indonesia menghadapi masalah yang cukup penting yaitu kinerjanya dalam merespon bencana masih rendah, kesadaran dalam penanggulangan bencana masih sangat rendah, dan partisipasi sekolah yang masih rendah. Oleh karena itu, akan banyak korban jiwa ketika terjadi bencana dan kurangnya kesadaran masyarakat tentang kerentanan bencana serta upaya mitigasinya. Menurut Sunarto (2012), anak-anak yang sangat rentang terhadap bencana, yang mungkin juga disebabkan oleh faktor-faktor disekitarnya sehingga mereka tidak siap menghadapi bencana. Menurut Desfandi (2014) pentingnya meningkatkan pengetahuan tentang bencana itu harus disosialisasikan terutama anak diusia sekolah dasar yang masih belum memahami tentang yang harus mereka lakukan jika bencana datang. Oleh karena itu pemerintah bersama dengan sekolah mengadakan peerapan pendidikan pencegahan di sekolah. Siswa membutuhkan pengetahuan dan kecakapan hidup terutama dikelas, agar siswa dapat bekerja keras untuk menyelamatkan diri dan membantu sesama jika terjadi bencana (National Research Council. 2007). panduan dalam bentuk kurikulum merupakan langkah strategis untuk memulai langkah pengelolaan bencana (disaster management) (UNDP, 1995). model mitigasi bencana tampak sangat 
mendesak dilakukan di indonesia. Alasannya adalah telah terjadi beberapakali bencana alam, seperti: gempa bumi, tanah longsor, angin puting beliung, banjir dan gelombang pasang.

UNDP artinya Mitigasi berarti melakukan tindakan untuk mengurangi dampak bencana sebelum datangnya bencana itu terjadi. Kegiatan mitigasi untuk berbagai kegiatan dan tindakan perlindungan yang dapatdiambil, dari entitas (seperti membangun struktur yang kuat) hingga prosedur (seperti teknik standar untuk memasukan penilaian bencana kedalam rencana penggunaan lahan) hingga prosedur.

Menurut Coburn (dalam Sejati 2014: 14) mitigasi adalah istilah yang digunakan untuk menunjuk pada semua tindakan yang dapat dilakukan untuk mengurangi dampak suatu bencana sebelum bencana terjadi, termasuk persiapan dan tindakan untuk mengurangi resiko terkait bahaya buatan manusia dan bencana alam yang diketahui, serta proses perencanaan bencana. Untuk secara efektif menanggapi bencana waktu nyata. Menurut Noor (2014) kegiatan mitigasi bencana bertujuan untuk meningkatkan kesiasiagaanpan ,mengurangan bahaya dalam jangka panjang, mengurangi jumlah korban, dan menerapkannya semaksimal mungkin untuk meminimalkan dampaknya. Menurut Sunarto (2012), anak-anak sangat rentang terhadap bencana, yang mungkin disebabkan oleh lingkungan di sekitarnya, sehingga mereka tidak siap menghadapi bencana. Menurut Desfandi (2014) pentingnya peningkatan pengetahuan tentang bencana harus disosialisasikan terutama bagi anak usia sekolah dasar yang masih belum memahami apa yang harus dilakukan jika terjadi bencana. Menurut Suharwoto, dkk. (2015) padahal, penyelenggaraan penanggulangan bencana memang harus ditanamkan kepada masyarakat secepatnya, bisa diterapkan melalui pendidikan sekolah formal mulai dari sekolah dasar. Sehingga ini meminimalkan jumlah korban yang terkadang diklasifikasikan sebagai anak-anak karena ketidaktahuan.

Selanjutnya menegani mitigasi, UNDP memberikan pengertian sebagai berikut: Mitigasi mengacu pada pengambilan tindakan untuk mengurangi dampak bahaya sebelum terjadi. Istilah mitigasi berlaku untuk berbagai kegiatan dan tindakan perlindungan yang dapat diambil, dari entitas, hingga rancangan hingga prosedur.

Menurut pendapat Djamarah metode demonstrasi adalah sesuatu penyampaian pelajaran dengan menggunakan alat peraga untuk dapat memberikan pembelajaran dengan yang lebih bermakna kepada peserta didik dengan melalui suatu proses, situasi atau benda tertentu yang ada disekitar yang nantinya akan dipelajari Pembelajaran mitigasi bencana, sekolah harus mengacu pada model pembelajaran yang aktif, inovatif, dan menarik. Model yang digunakan yaitu menggunakan model demonstrasi yang menerapkan peragaan untuk memperjelas suatu pengertian atau untuk memperlihatkan bagaimana untuk melakukan sesuatu kepada peserta didik sebagai salah satu model pembelajaran. Adapun inti dari tujuan ini bisa diketahui dengan sikap tanggap sebelum, saat, dan sesudah terjadi bencana.

Proses mengurangi bencana alam dibumi dimulai pada tahap pencarihan, yaitu mencari pemahaman penggetahuan peserta didik tentang bencana alam dan mendemonstrasikan masalah bahaya yang terjadi di bumi melalui model demonstrasi. Tahap selanjutnya akan memperkenalkan konsep bencana alam. Ini dilakukan dengan membahas pengetahuan yang baru mereka ketahui tentang bahaya yang terjadi di bumi, meringkas dan menstabilkan materi. Pada tahap akhir siswa melakukan kegiatan berbagi atau bertukar pendapat sehingga mereka dapat memahami konsep mitigasi bencana.

Berdasarkan uraian di atas dapat disimpulkan bahwa metode demonstrasi adalah cara mengajar yang dilakukan guru dengan menyajikan bahan pelajaran dengan mempertunjukkan secara langsung objek yang ditampilkan guru untuk membangkitkan minat belajar peserta didik dan menggiring peserta didik ke dalam proses pembelajaran aktif, kreatif, efektif, dan menyenangkan.

Proses metode mengurangi bencana alam dibumi dimulai pada tahap eksporasi yaitu mencari pemahaman pertama siswa tentang bencana alam dan mendemonstrasikan peristiwa kejadian alam dibumi dengan model demonstrasi. Tahap selanjutnya kan memperkenalkan konsep bencana alam bagaimana cara membahas konsep baru tentang bencana alam meringkas serta menstabilkan pemahaman. Pada tahap ini siswa melakukan kegiatan berbagai atau bertukar pendapat sehingga mereka dapat memahami konsep mitigasi bencana.

Langkah-langkah dalam metode demonstrasi yang harus dilakukan dalam pembelajaran adalah sebagai berikut.

a. Mempersiapkan alat bantu yang akan digunakan dalam pembelajaran

b. Memberikan penjelasan tentang topik yang akan didemonstrasikan

c. Pelaksanaan demonstrasi bersamaan dengan perhatian dan peniruan dari peserta didik

d. Penguatan (diskusi, tanya jawab atau latihan) terhadap hasil demonstrasi

Kesimpulan berdasarkan uraian diatas dapat disimpulkan bahwa penggunaan metode demonstrasi adalah pengajaran yang dilakukan oleh guru dengan memaparkan bahan pelajaran dengan mempertujukkan secara langsung objek yang ditampilkan oleh guru intuk membangkitkan minat belajar serta menggiring siswa melalui proses belajar aktif, kreatif, efektif dan menyenangkan. 


\section{KESIMPULAN}

Bencana alam adalah peristiwa yang dapat mengancam manusia dan juga dapat menimbulkan adanya kerusakan dilingkungan sekitar. Bencana terjadi diseluruh belahan dunia diantaranya gempa bumi, gunung meletus dan tsunami. Ada bencana yang dapat diupayakan untuk tidak terjadi tetapi ada juga bencana yang dapat diupayakan untuk tidak terjadi, tetapi ada juga bencana yang tidak dapat kita hindari. Jika direncanakan dan dilaksanakan secara benar, maka masyarakat sekitar dapat terbiasa dengan adanya bentuk praktek keselamatan yang berkaitan dengan bencana. Pendidikan preventif juga harus berfokus pada pembentukan keselamatan masyarakat yang berkelanjutan.

Pendidikan kebencanaan merupakan solusi internal yang dapat mengurangi dampak bencana alam bagi masyarakat untuk bersiap menghadapi bencana alam. Pendidikan berbasis masyarakat, pendidikan kebencanaan mendidik masyarakat lokal tentang bencana alam. Pendidikan kebencanaan dilaksanakan dengan model demonstrasi, dalam konteks penanggulangan bencana dengan mencakup bidang kognitif, afektif, dan psikomotorik. Oleh karena itu, perlu dilaksanakan studi kasus bencana alam. Maka dari itu, langkah-langkah mitigasi tidak hanya difokuskan pada manajeman bencana, tetapi juga pada pemahaman masyarakat. Tujuan mempelajari langkah-langkah penanggulangan bencana bagi anggota masyarakat adalah untuk meningkatkan kemampuan warga dalam merespon bencana pada saat, setelah dan sebelum bencana. Menyangkut peran orang dewasa siswa sekolah dasar, sangat penting bagi mereka untuk mempelajari keterampilan pengurangan resiko bencana.

\section{Acknowledgements}

Author would like to express grateful to Universitas Pekalongan for the funding to complete this study. This thankfull is extended to Research and Community Service Department (LPPM) who provided assistance and advice during this study. Warmest gratitude and appreciation especially goes to all of respondents and colleagues for being a kindhearted during data collection process.

\section{DAFTAR PUSTAKA}

[1] Eka Suarmika, P. 2017. Pendidikan Mitigasi Bencana Di Sekolah Dasar. Jurnal Pendidikan Dasar Indonesia. 2(2) : 18-24. (Online). Tersedia:

https://www.researchgate.net/publication/322130915_PENDIDIKAN_MITIGASI_BENCANA_DI_SEKOLA H_DASAR_SEBUAH_KAJIAN_ANALISIS_ETNOPEDAGOGI [20 Maret 2021]

[2] Gusti Ayu Tri A, I., dkk. Pengaruh Model Pembelajaran Mitigasi Bencana Terhadap Pemahaman Dan Ketahanmalangan Siswa. 46(2) : 97-105. (Online). Tersedia:

https://ejournal.undiksha.ac.id/index.php/JPP/article/viewFile/2660/2251[20 Maret 2021]

[3] Hayudityas, Beatrix. Pentingnya Penerapan Pendidikan Mitigasi Bencana Di Sekolah Untuk Mengetahui Kesiapsiagan Peserta Didik. Jurnal Edukasi Nonformal. 1(2) : 94-102.

https://www.google.com/url?sa=t\&rct=j\&q=\&esrc=s\&source=web\&cd=\&ved=2ahUKEwibvXwnYfwAhUTju YKHbVXBDAQFjABegQIAxAD\&url=https\%3A\%2F\%2Fummaspul.ejournal.id\%2FJENFOL\%2Farticle\%2F download\%2F407\%2F232\%2F\&usg=AOvVaw1kHSWCK3wxJ1Wdynj25KrV [20 Maret 2021]

[4] Kasmiati. Meningkatkan Hasil Belajar Siswa Dengan Penerapan Metode Demonstrasi Pada Mata Pelajaran IPS Kelas III MI Al-Hikmah Batu Bota. Jurnal Kreatif Tadulako Online. 4(9) : 212-220. (Online). Tersedia: https://www.neliti.com/id/publications/113021/meningkatkan-hasil-belajar-siswa-dengan-penerapan-metodedemonstrasi-pada-mata-p [20 Maret 2021]

[5] Nugroho, Agung. Pengembangan Model pembelajaran Mitigasi Bencana Gunung Meletus Di Sekolah Dasar Lereng Gunung Slamet. Jurnal Pengabdian Masyarakat Multidisiplin. 1(2) : 131-137. (Online). Tersedia: https://www.google.com/url?sa=t\&rct=j\&q=\&esrc=s\&source=web\&cd=\&cad=rja\&uact=8\&ved=2ahUKEwjn LbooIfwAhUVheYKHbpqAhEQFjAAegQIAxAD\&url=http\%3A\%2F\%2Fjurnal.univrab.ac.id\%2Findex.php\% 2Fjpm\%2Farticle\%2Fdownload\%2F413\%2F285\&usg=AOvVaw2VjE-JD4g89no4dD8sNwFr [20 Maret 2021] 
[6] Qurrotaini, L., Novita Nuryanto. Implementasi Pendidikan Mitigasi Bencana Alam Gempa Bumi Dalam Pembelajaran IPS SD. Jurnal Pendidikan Dasar. 2(1) : 37-44. (Online). Tersedia: https://journal.uwks.ac.id/index.php/trapsila/article/view/885 [20 Maret 2021]

[7] Rusilowati A. 2012. Mitigasi Bencana Alam Berbasis Pembelajaran Bervisi Science Environtment Technology and Society. Jurnal Pendidikan Fisika Indonesia. 8(2012) : 51-60. (Online). Tersedia: https://journal.unnes.ac.id/nju/index.php/JPFI/article/view/1994 [20 Maret 2021]

[8] Wayan Sumarniasi, Ni. Upaya Meningkatkan Hasil Belajar Siswa Kelas IV SDN 3 Kasimbar Melalui metode Demonstrasi Pada Pembelejaran IPS. Jurnal Kreatif Tadulako Online. 2 (4) : 83-100. (Online). Tersedia: https://media.neliti.com/media/publications/109384-ID-upaya-meningkatkan-hasil-belajar-siswa-k.pdf [20 Maret 2021]

[9] Wedyawati, N., Yasinta Lisa., Erma Ester Magdovia. Evektivitas Model Pembelajaran IPA Mitigasu Bencana Terhadap Hasil Belajar Siswa Sekolah Dasar. Jurnal Pendidikan Dasar Indonesia. 3(1) : 9-13. (Online). Tersedia: https://journal.stkipsingkawang.ac.id/index.php/JPDI/article/view/485 [20 Maret 2021]

[10] Wibowo, B., dkk. Disaster Mitigation Pop-up Book Sebagai Media Oembelajaran Mitigasi Bencana Berbasis Kearifan Lokal Bagi Siswa Sekolah Dasar. Geomedia. 15(1) : 61-74. Online). Tersedia: https://journal.uny.ac.id/index.php/geomedia/article/view/16236 [20 Maret 2021] 